\title{
A Head with Two Tales: Trade Unions' influence on Temporary Agency Work in Belgian and German Workplaces.
}

Valeria Pulignano and Nadja Doerflinger

Center for Sociological Research (CeSO), Katholieke Universiteit Leuven, Belgium

Corresponding author:

Valeria Pulignano

Centre for Sociological Research (CESO)

Faculty of Social Science

Parkstraat 45 bus 3601

3000 Leuven (Belgium)

Tel: 0032 (0)16 323162

Fax: 0032 (0)16 323365

E-mail: valeria.pulignano@soc.kuleuven.be

Please note: this article was published as:

Pulignano, V., Doerflinger, N. (2013). A head with two tales: trade unions' influence on temporary agency work in Belgian and German workplaces. International Journal of Human Resource Management, 24 (22), 41494165. 


\begin{abstract}
The paper investigates local trade union influence on temporary agency work in four Belgian and German workplaces. It argues that the union's capacity to influence the job conditions of agency workers is heterogeneous. Societal differences between systems of workplace representation and the different structures of collective bargaining are used to explain the heterogeneity of local union practices and their effect on the working conditions of agency workers. These societal differences intersect with the socioeconomic conditions of the firm to generate local unions' responses to the management's use of agency workers.
\end{abstract}

Keywords: employment relations, human resource management (HRM), temporary agency work, trade unions, workplace representation

\title{
Introduction
}

Temporary agency work (TAW) is one of the most evident forms of vulnerable and precarious employment (Fudge, 2011). Agency workers need to cope with job insecurity and they are easily entrapped in a series of temporary jobs negatively influencing their professional identity, personal relationships and, consequently, their own existence (Di Nicola, 2009). The share of TAW has been growing rapidly over recent decades (Håkansson and Isidorsson, 2012). A study of the International Labour Organisation (2009) shows that their number more than doubled globally from around 4.5 million in 1997 to 9.5 million in 2007, and temporary staffing levels more than trebled in some European economies.

Although literature exists on the challenges TAW poses to trade unions (Heery, 2004; Lundy, Roberts and Becker, 2006) and HRM (Ward, Grimshaw, Rubery and Beynon, 2001; Connell and Burgess, 2002; Koene and van Riemsdijk, 2005; Hall, 2006; Mitlacher, 2008), there is still need to investigate how strategic HR decisions in using temporary workers are formed within firms and which factors shape them. Consistent literature in HRM focuses on studying the conflict, tensions and contradictions associated with the use of TAW. It emphasises that the HRM strategy can range from short- to long-term (Bolton, Houlihan and Laaser, 2012). However, the practices local unions develop as a response to the HRM strategy, their influence and the outcomes this produces for the job conditions of agency workers have hardly been considered.

Recent accounts on union activity towards TAW have attempted to provide alternative frameworks. Drawing on Hyman's (2001) typology of union identity, Heery (2004) illustrates that unions can choose between 'accepting' or 'rejecting' TAW. Heery identifies four types of trade union responses to agency work: exclusion, replacement, regulation and engagement. At the core is the need to conceptually connect the union attitude towards TAW to union identity to understand why unions approach the insecure workforce differently. Union identities are tied to specific national contexts (Hyman, 2001). Heery and Abbot (2000) summarise five types of union identities towards contingent work: exclusion, servicing, partnership, social 
dialogue and mobilisation. Exclusion refers to a union's formal rejection of agency workers. Partnership indicates that the union protects existing members' interests through 'productivity coalitions' with management. Dialogue and mobilisation refer to the logic of inclusion with the union attempting to improve the conditions of TAW through either corporatist behaviour with the state or class struggle. Servicing is based on the union's acceptance of agency workers while defending the interests of its own members (as in partnership) or simply because they perform individual servicing to the needs of the members. Nevertheless, arguing that union identities can be tied to different unions' responses to TAW does not tell the whole story. Heery and Abbot (2000) indicate that internal tensions can arise between different union strategies. Bergström and Styhre (2010) found that unions may co-align between different apparently opposite "institutional logics", the acceptance of the use of TAW in practice while maintaining resistance in principle. In addition, external labour markets, government regulations, institutional forces and HRM strategies constrain the adoption of particular union behaviours in a way that local practices cannot be treated as a matter of 'free' choice (Pfeffer and Cohen, 1984). This paper emphasises that local union practices towards TAW play out on a firm-level field which management continuously contributes to shape. The interaction between the external environment and unions' responses to the changing strategies of HRM on TAW affects the extent to which the job conditions of agency workers can be effectively enhanced. These will depend on the societal context in which unions and firms operate. This helps clarify why trade unions' general policy and workplace practices may sometimes diverge.

Trade unions' approaches towards TAW may be affected by the human resource management's growing use of temporary labour. In particular, the rapid expansion of nonstandard work has led to a move from 'dualism' towards a more 'fragmented' landscape of labour relations (Rubery, 2005; Holst, 2013). This increases pressure on the 'core' workforce by stimulating change in standard employment relations (Bernhardt and Marcotte, 2000). As a consequence of shrinking standard employment, unions may become more inclusive towards TAW (Lillie, 2011). Hence, in order to understand trade unions' approaches towards TAW, it is important to explore unions' local practices as a response to the HR management's use of agency work. Do union responses to the HR management's use of TAW contribute to understanding how strategic decisions on TAW are made at the workplace, and how? Do trade unions monolithically approach TAW at the workplace or are polarized responses possible, and why? These are the key research questions informing this paper.

In the paper it is argued that societal differences (Maurice and Sellier, 1986) in the systems of workplace representation and collective bargaining, to which in turn union identities are tied, explain the different practices unions adopt locally towards TAW. They contribute to understanding different labour use strategies of TAW. These societal factors embedded into distinctive systems of employment relations - intersect with the firm's socioeconomic conditions. Trade unions adopt strategies as responses to the distinctive, changing HRM approaches towards TAW (Doellgast et al., 2013). These changing management approaches are reflected in the evolution of strategies pursued by employee representatives and implemented in negotiations whose outcomes remain contingent upon the national labour 
regulation. Moreover, different local union attitudes account for different union behaviours and their effects on the working conditions of agency workers. Specifically, we refer to the union's capacity to contribute to reducing the vulnerability of agency workers. We draw from a comparison of four case studies of two multinationals in the automotive sector operating similar Belgian and German workplaces. In Belgium, plant-level bargaining mainly dealt with limiting the number of agency workers and maximizing their job protection. The Belgian HR managers saw the advantage of moving beyond the stylised core-periphery dichotomy, and to use TAW as a 'strategic' long-term response to market uncertainty. Specifically, they were in favour of converting temporary to permanent contracts by offering a first step into a possible career path and strengthen the 'fit' between the workers and the organisation, thereby enhancing the agency workers' commitment. This was supported by the strong local unions' negotiating practice of continuous training and career prospects towards regular jobs with the local HR management. Belgian unions' approaches were tied to their distinctive encompassing identity which can be traced to incorporating TAW into central (sector) agreements while negotiating employment prospects for them. By contrast, in Germany, the HR management took a short-term view of the use of TAW. Their commitment to no compulsory redundancies was a critical element in its coalition arrangements with the works councils as the main form of employee representation at the establishment level. On the other hand, the progressive advancement of 'opening clauses' in collective agreements led to the shift of bargaining power from sectoral interest representation to works councils. As their primary concern of works councils was to support job stability, particularly in situations of firms' cost pressure, continuous restructuring and job insecurity, a high share of agency workers became functionally equivalent. Works councils were forced to agree on plant-level concessions where the acceptance of TAW was traded off against maintaining the 'core' workforce's privileges.

We begin by explaining the regulatory settings and general union attitudes towards TAW in Belgium and Germany. After the methodological section, we examine the local practices and discuss their implications.

\section{Regulating agency work and union approaches in Belgium and Germany}

The Belgian and German systems of labour relations have faced changes since the mid-1990s. Intensifying product market competition has not only prompted a re-orientation of the bargaining agenda, but also compounded the pressures for decentralisation of collective bargaining. Decentralisation has become a feature of Belgian industrial relations. However, inter-sector and sector-level agreements play a significant role despite the increased number of company agreements. With a collective bargaining coverage rate of 96 percent, Belgium scored highly among European countries in 2007-2009 in relation to bargaining coordination (in terms of a mixture of inter-sector and sector bargaining) and centralisation (in terms of the presence of inter-sector bargaining and additional sector or company bargaining) (European Commission, Industrial Relations in Europe Report, 2010:41 and Industrial Relations in Europe Report, 2012). Moreover, the Belgian 1968 labour legislation does not foresee the possibility of sector- and company-level deviations from inter-sector (and sector) collective 
agreements that go below the standards set at the inter-sector (and sector) level (Pulignano, 2012). This is why 'opening clauses' are not common in sector-level agreements and, if they are present, their use is regulated via local agreements between the employer and employees or ratified in a decision from the relevant sectoral joint committee (Paritaire Comité/Commissions Paritaires). However, sectoral minimum wages are excluded from 'opening clauses', which concern retirement regulations and working-time flexibility. Conversely, in Germany, 'opening clauses' have allowed companies to deviate from collectively-agreed wages and working conditions in order to maintain and improve firm competitiveness (Bispinck and Schulten, 2002). It has been argued that 'opening clauses' expanded the scope for bargaining by works councils on local issues concerning working-time flexibility, work organisation and wage flexibility (Eurofound, 2006).

Although where TAW 'opening clauses' were not specifically needed to be used as an instrument of legislative deregulation ${ }^{1}$, it is remarkable that in Germany the legal framework for agency workers (Arbeitnehmerüberlassungsgesetz $A \ddot{U} G$ ) permits deviations from the provisions for equal treatment set by law, provided these are made by collective agreements at the sector-level. This implies that agency workers are not covered by the sector-level agreement covering the user firm, but by the agreements of the TAW sector. By contrast, in Belgium, collective agreements at the sector level build on law and therefore they do not allow for deviations. Collective agreements for the TAW sector in Belgium are concluded through the joint committee structure number 322 (Eurofound, 2008). Although these agreements do not make reference to employment conditions in user companies, equal treatment is stipulated by law and may refer to the sector- or company-level agreements which cover the user firms. However, in Germany agency workers and permanent workers at the user enterprise are covered by different collective agreements, causing differences in their treatment. Even the European Union (EU) Directive on Temporary and Agency Work which, in principal, prescribes equal pay and treatment, does not rule out these differences. This is because, according to German law, the Directive does not apply if a valid collective agreement is in place. This exception is based on the assumption that agreements negotiated and concluded with a trade union representing the interests of employees can be deemed appropriate and fair, leading to the fact that no additional protection through the equality principle is required. In Germany, the Christian trade union confederation utilized this loophole and negotiated agreements with parts of the agency work sector, setting employment conditions which were below the usual standards negotiated by IG Metall as the main German trade union in the metalworking sector.

While German unions had opposed TAW for a long time, they were forced to change their attitudes in the 1990s due to persistently high unemployment and the unsustainable approach of labour shedding (Holst et al., 2010). As a response to the pressure to achieve more flexibility in the labour market, DGB (main German union confederation) deleted its request for a legal prohibition of TAW from its policy programme in 1996 and, in 1998, started to discuss how to put TAW on the bargaining agenda. In 2002, both IG Metall and the service sector union Ver.di (responsible for temporary work agencies) were involved in the revision of the 1972 Manpower Provision Act (Arbeitnehmerüberlassungsgesetz, AÜG). 
Generally, the 2003 liberalisation and the Hartz reforms of the German labour market led to a growing share of TAW, creating more employment through increased use of external flexibility. The equality principle was at the core of the law revision. To prevent wage competition between atypical and standard employees, the principle of equal pay and equal treatment was agreed upon. Nevertheless, the presence of sector-level collective agreements (Tarifvorbehalt) could opt out of this principle. German employers started to quickly negotiate collective agreements with the Christian trade union federation CGB, establishing comparatively low pay and bad working conditions for agency workers. This put pressure on the DGB trade unions and their bargaining capacity to negotiate good collective agreements for TAW. Accordingly, the gap in wage and working conditions between regular and agency workers increased. The deregulation of TAW in Germany led to a boom of the whole sector with the number of staff climbing from 300,000 in 2004 to more than 900,000 in 2012 (Bundesagentur für Arbeit, 2013). In particular, in the metal sector where the highest concentration of agency work can be found, IG Metall has actively engaged in reducing the negative effects for agency workers and in limiting wage competition. Together with Ver.di, IG Metall initiated several campaigns to organise agency workers and thereby stressed the union's changed strategy of inclusion towards TAW since mid-2000s (Wölfle, 2008). Starting from clear opposition, German unions now engage with TAW. The agreement IG Metall initiated in 2012 is relevant in this respect as pay premiums for agency workers, depending on the duration of work in the same establishment were agreed upon as well as the obligation to offer fixed-term employment after two years of working for the same user firm. In addition, IG Metall and Ver.di follow a strategy of representative participation by building up the necessary structures to organise agency workers. Finally, campaigns have become an instrument for mobilisation in favour of agency workers' social rights.

Belgian trade unions' approaches towards TAW are also inclusive, but illustrate more stability in the way they evolved compared to their German counterparts. When the law on TAW came into effect in 1987, unions were reluctant because temporary jobs were perceived as more precarious than regular jobs. However, the Belgian unions have never opposed TAW but rather engaged in creating an appropriate regulative framework where agency workers have similar social rights and entitlements to regular workers. In particular, CSC/ACV and FGTB/ABVV have contributed to creating awareness of TAW by organising local events to educate agency workers about their rights (Perin, 2008). This is particularly the case in the metal sector, where unions have been active in organising agency workers. ${ }^{2}$ Currently, Belgian unions are campaigning for a prohibition of daily contracts in order to increase agency workers' job stability (ACV, 2010). By limiting the deployment of agency workers in firms while providing similar coverage in terms of wages and working conditions compared to permanent workers, Belgian unions aim to create more equality and job stability for the workforce overall.

Hence, although both Belgian and German trade unions foster inclusive strategies towards TAW, there have been marked differences in the method. When TAW emerged, Belgian unions got actively involved and pushed for regulation whereas German unions remained passive for a long time, demanding a legal prohibition of TAW. As the following 
sections underline, these differences are reflected in the local union practices towards TAW and the effects on the job conditions of these workers.

\section{Methodology and research design}

The paper is based on a comparative case study analysis of four workplaces of two American multinational companies operating in the automotive sector, located in Belgium and Germany. The research was carried out during 2011 and 2012 and looks retrospectively at employment practices within each plant during 2002 and 2012. The two companies Autol and Auto2 were selected primarily because of their similarity. Comparisons across production sites within the same firm are illustrative because headquarters' policy towards TAW is similar. We also hold the nature of the production process constant. The case studies are as follows:

- $\quad$ Autol is an American multinational within the automotive supply sector, employing approximately 24,000 people worldwide (mostly blue-collar). Autol manufactures various low-tech products and components and is highly dependent on its customers which generate about 40 percent of the company's revenues. Due to emerging competition from South-East Asia, Autol must be able to flexibly react to customer requirements. This causes both permanent cost-pressure and flexibility needs stemming from customers' changing needs in terms of production volume. Within Autol, two highly unionised production units of similar size (1,500-1,600 employees) are examined - AutolBE in Belgium and AutolDE in Germany (see Table 1).

- $\quad$ Auto2 is an American conglomerate operational in various manufacturing subsectors one being the automotive supply industry. Its 130,000 staff (mainly blue-collar) are distributed globally. Auto 2 manufactures a wide range of mostly low-tech components for the automotive industry. Although Auto 2 is the leader in many of the markets it serves, it faces high competition particularly in the automotive supply sector. Similar to Autol, costcompetitiveness and flexibility have become even more pronounced due to growing competition from Asia. The two plants under consideration - Auto2BE in Belgium and Auto2DE in Germany - are highly unionised and similar in size with about 1,700 to 2,500 staff (see Table 1).

The unions represented in both Belgian plants are the Confederation of Christian Trade Unions ACV/CSC (Algemeen Christelijk Vakverbond/Confédération des Syndicats Chrétiens), the Belgian General Federation of Labour ABVV/FGTB (Algemeen Belgisch Vakverbond/Fédération Générale du Travail de Belgique) and the Federation of Liberal Trade Unions of Belgium CGSLB/ACLVB (Centrale Générale des Syndicats Libéraux de Belgique/Algemene Centrale der Liberale Vakbonden van België). In Germany, workers at the two workplaces are represented by IG Metall, Germany's metalworker union. However, in AutolDE there is also a small share of members belonging to the Christian metalworker union, CGM (Christliche Gewerkschaft Metall). 
The similarity across the workplaces in terms of union presence and company characteristics allows to investigate whether similar HR and union approaches towards TAW have evolved. In particular, the paper explores whether local unions that adopted dissimilar practices were able to exert influence on the agency workers' working conditions. In this respect, the comparison between Germany and Belgium is particularly interesting since these countries are characterized by differences in union tradition and worker representation systems. More importantly, trade union membership in Germany is much lower than in Belgium, and this influences the outcome of collective bargaining as the balance of power in decentralised Germany risks skewing towards the employers (Houwing, Keune, Pochet and Vandaele, 2011). Local management emphasised product market volatility and fluctuating workloads as the main drivers for utilizing TAW across the four plants. In all workplaces, the production process is based on an automated assembly line, with workers performing manual assembly and packaging functions along this assembly line. Therefore, the rigid, continuous production process provided few opportunities to separate the agency workers from the regular workforce. Additionally, all workplaces have suffered from restructuring due to intensifying competition, cost pressures and the crisis.

\section{[Table 1 about here]}

The comparative study is based on 35 semi-structured interviews. In both firms we interviewed the European-level management for HR to learn more about the companies' strategies, the respective plant managers in both countries to gain insight on the plants' particularities as well as several (strategic and operational) HR managers to understand local policies and practices as well as the negotiations leading to their implementation. Furthermore, we talked to works councillors and trade unionists (of all trade unions represented) at the local level to shed light on their positions and perceptions of negotiation processes with local management and to specialists on TAW at the sector level. This approach gave us a good overview on the union responses to the HR management's use of TAW. Each interview took between 60-120 minutes and was recorded and transcribed. NVivo was used as software tool to systematically analyse the data. Company-based documentary materials, copies of collective agreements and company-level agreements were used as secondary sources to complement the interview findings.

\section{Local unions' practices and job conditions of agency work in German and Belgian workplaces}

In the workplaces under investigation, the common HRM practice is to use temporary contracts to accommodate unpredictable market fluctuations. Such arrangements provide the firms with numeric flexibility advantages. We may expect trade unions to resist the deployment of TAW for the reasons outlined. However, we observe that unions do not only respond differently to the HR management's use of TAW, but also that the working conditions of agency workers differed remarkably across the four workplaces. Company-level agreements have been pushed by employee representatives in all workplaces to agree maximum thresholds of agency workers. Although a quota is utilized to limit the use of TAW, 
the reasons and social dynamics which accompanied the local negotiations across the workplaces differ substantially.

In 2005, Auto1DE implemented a quota for blue-collar agency workers of maximum of 15 percent of the total headcount, and 40 percent during the holiday periods. The works council initiated the negotiations with HR management to cope with the plant's difficult economic situation and, at the same time, reduce the workload for both parties in handling TAW. This is because in Germany, law obliges management to formally request permission for using agency workers from the works council, and the works council decides on each request. This bureaucratic system caused a high workload and created uncertainty for management, as it always faced the possibility of a works council disagreement. This uncertainty added to the pressure management was facing during periods of high market fluctuation. Thus, as both parties - works council and HR management - arguably benefited from the quota, negotiations went smoothly:

"We came to an agreement quite fast. With the quota the management is able to act flexibly within the assigned threshold. Even as a member of the works council you cannot just say that agency work is bad, because you know that the company needs the flexibility to deal with large orders. Of course the situation of agency workers is not the best, but we definitely need an instrument to balance out the fluctuations in daily business."

(Works councillor, AutolDE)

The quota reduced the bureaucratic efforts to practically arrange using TAW and therefore, it became more locally accessible. The agreement contributed to protect the core workforce and to safeguard the plant. Specifically, AutolDE could benefit from labour cost savings by the relatively large size of its flexible workforce as the price of TAW in Germany is low compared to regularly employed workers. For companies like AutolDE facing harsh competition from the emerging markets, finding ways to save costs is pivotal for the survival of a plant. This was particularly important during the economic crisis when management was forced to cut even more costs. By sending all agency workers back to the agency, the company could reduce staff in the plant without paying dismissal costs. Therefore, 'liberalising' the use of TAW implicitly increased the job security of the core workforce.

"Agency work was officially introduced to cope with large volume orders and to provide flexibility. But now we see that those workers are mainly hired in order to cut costs."

(Works councillor, Auto1DE)

Likewise, a TAW-quota of 20 percent was negotiated in Auto2DE in 2004. The works council initiated the negotiation originally seeking to conclude an employment guarantee, while management aimed at raising the level of internal and external flexibility. Prior to these negotiations, Auto2DE faced intensive restructuring, cutting almost 150 jobs. Because of declining order volumes and rising cost pressure, the HR management made clear that without adapting its personnel policy, the plant would have gone into bankruptcy soon ${ }^{3}$. In this situation, the works council pushed for an employment guarantee in exchange for agreeing to 
higher levels of flexibility. As a result, a 20 percent quota of TAW and a "collective agreement on securing the plant" (Standortsicherungstarifvertrag) were implemented. Thus, the job security of regular workers was traded off against the flexibility of agency workers.

"If we give something to the company, we want to have something back, too. But the management agreed on securing the location for the future."

(Works councillor, Auto2DE)

Thus, the constant fear of plant closure could be minimised due to a high level of external flexibility buffering the regular workforce. At the same time, the HR management found a way to increase both internal and external flexibility while saving labour costs which proved to be beneficial for the difficult economic situation of the plant.

By negotiating a maximum threshold for the use of TAW, AutolDE's and Auto2DE's works councils engaged in concession bargaining with the local HR management. Thereby, they responded to the HR management's approach towards TAW by accommodating the request of higher flexibility and cost cutting in exchange for no dismissals. However, while agency workers contributed to increase flexibility and reduce costs and, therefore, save regular jobs, the core workforce had to make financial sacrifices too. While AutolDE stopped paying a weekend premium ${ }^{4}$ for Saturday work, Auto2DE reduced all pay premiums exceeding sector-level agreements. Specifically, premiums for shift work were brought back to the level of the sector agreement and all other voluntary pay premiums were cut by 50 percent ${ }^{5}$. Therefore, the increased security for the core workforce comes at a price.

Generally, the agreements increased the job security for the core workforce while deteriorating the working conditions and job stability of the agency workers. As a user firm does not have any contractual relationship with its agency workers, it can flexibly send them back to the agency if they are not needed anymore. Moreover, terminating the 'employment relationship' does not depend on legally binding transition periods and does not produce costs like severance payments. This 'cheap dismissal' provides an incentive for the user firm's HR management to deploy agency work to react to crisis periods, as indicated by Auto2DE's HR manager:

"It is a flexible workforce; as always when you have peak employment agency work makes a lot of sense because when this peak is gone, it's quite easy to reduce your workforce to an acceptable level without the need to terminate the jobs of people in your team."

(HR Manager, Auto2DE)

However, HR managers in both German plants faced 'dilemmas' when using TAW, especially relating to lower levels of motivation and commitment. The HR management sought to resolve this problem by means of pay incentives, but they were by far too limited to close the pay gap between regular and agency workers. In Auto2DE the respective companylevel agreement from 2004 entitled TAW to a gross premium of 1-1.50 Euro per hour for an 
assignment from six months onwards. But as agency workers were mostly used for short-term assignments, only a minority of them could actually benefit. In 2011, AutolDE entitled agency workers to team performance pay premiums on a monthly basis. Depending on the performance of the whole team, every member - independent of contractual status - got the same premium. While pay premiums should enhance motivation and commitment of agency workers, the HR management at the same time used this measure to introduce coercive comparisons across regular and agency workers. In AutolDE, the team premium put pressure on the 'core' workers to enhance their level of productivity since regular and temporary workers - who worked side-by-side, doing similar tasks - were entitled to the same level of pay premium. In Auto2DE, the premiums functioned as 'stick and carrot' mechanism to enhance performance but not commitment among TAW. Overall, there was no equal treatment between regular and agency workers in the two German workplaces. The main reason is rooted in the current collective agreements ${ }^{6}$ for the TAW sector. In contrast to the IG Metall agreement covering regular workers, the one for agency workers contains lower pay premiums for weekend and night work and only minimal Christmas and holiday allowances. The minimum wage for agency work is substantially lower than average wages of regular workers in the metal sector. Although the company-level agreements regulating the extent of TAW by means of a quota at both German workplaces included pay premiums, there was still a gap in terms of pay, working conditions and job stability.

This highlights the German works councillors' position of 'replacement' (Heery, 2004), implying that they accept agency workers as members of the labour market and potential union members. However, agency workers are treated as a 'buffer' helping to protect the employment of core members. Specifically, the acceptance of the relatively high share of TAW emerged at the risk of job losses and plant closure and was, therefore, instrumental for safeguarding employment. Facing economic pressures, works councils responded to these by engaging in concession bargaining which decreased the risk of job losses and plant closure. At the same time, strategic HRM policies used TAW with a short-term view, considering it a cheap way to 'buffer' fluctuations in a cyclical industry and to counteract economic difficulties. This had negative effects on the morale and commitment of the agency workforce.

In both Belgian workplaces, the HR management and local unions negotiated a threshold on the use of TAW. Negotiation followed the fact that there was no possibility to derogate from sector-based agreements enforcing the equality principle for agency workers. Moreover, in both Belgian plants unions could use the regulatory framework to oppose high levels of TAW. The result was a much lower threshold compared to the German plants since there was less scope to use TAW for cost purposes. In this sense, the HRM strategy was moderated by unions not accommodating around a high use of TAW because of the regulatory system. The social dynamics put in place by the local negotiations were prone to enhance equality. At AutolBE, the HR management and local unions agreed on a 15 percent flexibility quota in 2004, including 10 percent fixed-term and 5 percent agency work in the aftermath of a serious dispute on the use of temporary contracts between HR management and unions: 
"We had to go into mediation. There was a dispute because we had some people who were too long in interim contracts. Moreover, the union feared that we wanted to reduce our workforce step by step without restructuring. So the amount of fixed labour was also a topic in our negotiations."

(HR Manager, AutolBE)

Local union representatives pushed for an agreement to keep the use of TAW at a minimum and, in so doing to avoid that agency work could be abused. As a union representative explains:

"If the company uses more than 5\% agency work they pay it back to the workers by offering more permanent contracts. Moreover, we have a formal system for entering the company regarding blue collars; firstly they get in with an agency work contract, then they become temporary workers and finally after two years, they get a permanent contract."

(Works councillor, AutolBE)

Consequently, the three parties involved arguably benefitted from the agreement. By hiring staff via a work agency, the HR management could make use of an extended probation period and screen workers on-the-job. The unions achieved a low threshold of TAW and negotiated a formalized employment path. Finally, agency workers were given long-term prospects in the company which had positive effects on their motivation, commitment and performance which, in turn, corresponds to the HR strategy. If the worker performs well in the temporary period, the company normally offers a fixed-term contract and, after two years, permanent employment.

In $A u t o 2 B E$, the union representatives and the HR management negotiated an agreement on the ban of TAW in 2007 due to the union's perception of overusing it. In exchange, the unions agreed to a more extensive use of fixed-term contracts, which account for 20 percent of the workforce following the current HR strategy. A works councillor explains:

"As trade union we made clear we did not want agency workers. The company does not have a choice because it already has a strong flexibility with the workers with fixed-term contracts and we decided that we could not agree to everything either."

(Works councillor, Auto2BE)

Asked about the ban of agency work, the HR manager in Auto2BE states:

"We don't use agency work because we think that it's better to have only one workforce. The fixed-term contracts - it's the same. They have the same pay scheme, the same advantages as the others and they are Auto2BE employees, so there is no difference. We use other forms of flexibility which allow us to screen workers for permanent positions. We have a big problem here in the plant: this is to find good skills and specialised workers." 
The local unions' agreement on augmenting the level of external flexibility via fixedterm workers was a precondition for the HR management abandoning the idea to use TAW in the first place. However, the HR managers arguably perceived the amended contractual strategy as advantageous, due to the enhanced motivation and commitment of temporary workers, the fact that having one workforce lowers the potential of conflict between different groups of workers and because of the 'screening' function. Screening workers for permanent positions by trying them out in fixed-term arrangements lowers the cost of dismissing workers who demonstrate low productivity. From the union side, there is little reason to believe that the arrangements negotiated at both Belgian workplaces would result in less job stability for the temporary workers due to policies on formal procedures on entering the company. This means starting with temporary contracts which are subsequently upgraded to permanent ones after not more than three years in case of good performance. Throughout the process, there are periods of on-the-job and general training. Union representatives and HR managers agreed on providing training for all workers regardless of their contractual status; treating them differently was out of question:

"They start the training once they arrive here since you don't know yet if they are going to receive a permanent contract later or not. So they all get the same vocational training. Some of those who don't get a permanent contract here find work with our subcontractors because they already worked here."

(Training specialist, Auto2BE)

In AutolBE, the HR strategy considers investing in specific training as essential to retaining a skilled and experienced workforce. This has process-related advantages for the company in being more conducive to maintaining cooperative relations with the workforce, which contributes, in turn, to a high level of voluntary mobility and therefore flexibility.

The recent economic crisis challenged the Belgian workplace's approach towards TAW. When the downturn reached its peak and order volumes plummeted, both companies reduced their flexible workforce for the sake of the plants' survival. The HR management and unions had to face the fact that their long-term strategy regarding TAW worked out best in times of economic growth. However, when concluding the agreements, neither HR management nor unions anticipated a scenario for TAW in times of crisis. On the contrary, the HR managers pointed out that because of the forced reduction of agency workers when the crisis aggravated, they lost essential skills which were scarce in the labour market later on. AutolBE's HR manager explains:

"We stopped a lot of agency contracts, but we lost a lot of skills by doing that. Unfortunately, a lot of skills were with our flex labor, which is not smart to do. Maybe we can keep the level of flexibility, but we should change the way we deal with flexibility. We should not just say 'the more is better', but try to have a 'smart flexibility' - this is what we really need." 
Therefore, AutolBE is currently reconsidering its strategy towards TAW in the aftermath of the crisis. Keeping a long-term focus is crucial, as providing prospects is important for not losing skills, motivation and commitment. Yet, reducing the 15 percent flexibility-quota in exchange for a higher level of flexibility among the core workforce was under discussion during the period the research was conducted. Similarly, Auto2BE's HRM strategy towards TAW was also contingent upon growth without taking into account the possibility of a crisis. Most of the staff that left during the crisis has been rehired, particularly to replace retirees.

Overall, the aforementioned policies and practices in both Belgian workplaces stress the long-term HR perspective in terms of TAW. Agency workers are considered a resource, therefore formalized employment paths and extensive training were negotiated. This approach is also likely to benefit the agency workers' motivation, commitment and performance. At the same time, Belgian unions favour 'regulation'. In this case, unions accept agency workers as equal members featuring an inclusive, encompassing strategy.

\section{Understanding Belgian and German unions' local practices: the two tales}

Product market fluctuations increased pressures for the local HR management to use TAW within German and Belgian workplaces. Both the economic crisis and restructuring projects caused difficulties for this HR strategy in terms of maintaining organisational commitment with changing economic conditions that required the need to reduce the workplace's headcount and to cut costs. Empirical evidence illustrates that this entailed rapid changes in human resource strategy whose nature (e.g. implementation of quotas, changing conditions for regular workers alongside changes to temporary workers, coercive comparisons etc.) was contingent upon improving performance. This expanded the scope for negotiations with employee representatives over local issues, such as flexible staffing arrangements, but it also affected the extent to which coordination between the national (sectoral) trade union approaches and the works councils' local practices towards the use of agency workers could be maintained. This is particularly the case in the two German workplaces, where the advancement of 'opening clauses' reflects a shift of bargaining power within the dual system of representation from sectoral interest representation towards the works councils. As both sides' primary concern was to safeguard the job security of the 'core' workforce, the plantlevel agreements concluded at Auto1DE and Auto2DE by the works councils and local management contain 'productivity-oriented' concessions. This reiterates management's shortterm view on the use of TAW. Accordingly, agency work is a less expensive way to cope with short-term contingencies such as market fluctuations. Given the option of replacing external by internal adaptability, from a works councils' perspective, accepting more external flexibility which can offer a 'security net' in terms of job guarantees for the 'core' workforce may be acceptable.

The presence of workplace-level agreements can be interpreted as the response of the German works councillors to the HR management's short-term view on TAW to safeguard employment while contributing to retain the 'core' workers, and so to enhance the competitiveness of the firm by reducing costs. Furthermore, bargaining decentralisation in 
Germany has undeniably exacerbated the already existing tensions between the local works councils' practices and the general sectoral unions' inclusive approach towards TAW. Within both German workplaces, IG Metall had to contend with a new economic and political regime, one in which increasing deregulation in the German labour market allowed firms to become more competitive by applying a mix of atypical employment, opting out of collective agreements and making more use of diversified flexibility arrangements. Within Germany's dualistic social structure and under the increased threat of restructuring, works councils were forced into local concessions undercutting sectoral collective agreements, while trying to pacify capital by following the logic of 'productivity-coalitions' - even despite the late turn of IG Metall towards inclusion (Heery and Abbot, 2000). The latter extends to Heery's (2004) logic of union 'exclusion' which reiterates Hyman's (2001) typology of the German union identity being between market and society. On the other hand, and in line with other studies, German works councils' decisions to agree on local concessions suggest that even established sources of bargaining leverage can be undermined by increased cost-based pressures and shifting organisational and HR strategies (Doellgast, 2008). By negotiating concessions on job and income protection for the 'core' workforce, German works councils have not contributed to reducing pay gaps, enhancing working conditions and creating long-term employment prospects for agency workers. On the contrary, they contributed to institutionalising disorganisation in that the system is unable to improve the social conditions of agency workers. German workplaces remained poorly regulated regarding TAW and agency workers could not have their interests effectively represented by benefiting from the general sectoral union policy of inclusion. Conversely, concessions became an organisational strategy to increase competition within workplaces by putting pressure for performance on the overall workforce. This was beneficial for the HR management in terms of cutting costs and at the same time, increasing performance due to the aforementioned increased competition.

The use of agency employment is well-regulated by Belgian law and collective agreements. User companies' agreements cannot derogate through 'opening clauses' but only add to them. Moreover, working conditions for agency workers are similar to any other worker executing the same tasks in the same company. By following the main national (sectoral) trade union policy, the local union representatives did not reject agency work but negotiated its use with management. Belgian employers saw the advantage of improving the contractual conditions for TAW by shifting their expectations from short- to long-term relationships. This was also contingent upon the management's expectation of the strong Belgian unions' reaction. By adopting a long-term HR approach, management could minimise the risk of union opposition. By retaining low levels of agency workers, unions were able to gain control over the plant-level regulation of TAW. This implied that better working conditions could be locally negotiated and jointly guaranteed. These basically consisted of extra training arrangements which the firm provided beyond the legally required job-related training. This enhanced the scope for agency workers to progress with their career towards better and stable employment.

The Belgian HR management's strategy of fostering long-term job perspectives contributed to enhance productivity among temporary workers while eliciting motivation. It 
can also be argued that the presence of union-dominated works councils allowed unions in both workplaces to use their strength to push for local negotiations on the improvement of the working conditions for TAW. Moreover, the articulation between local and central (sector) level unionism, typical of the Belgian system of employee representation, in accordance with which unions - especially in large firms - have a strong presence at the workplace via uniondominated works councils, restricted the risk of concessions by derogating from central agreements as in Germany. The Belgian tale on the local unions' practices towards TAW, and the effects on the working conditions of these workers, in turn, reflects the distinctive encompassing identity of Belgian unions which, by following Hyman's typology (2001), can be positioned between society and class.

\section{Conclusions}

It has been argued that TAW constitutes the basis for the emergence of a growing regime of precarious employment (Allen and Henry, 1997). Accordingly, commentators have emphasised that trade unions and HR management face different 'dilemmas' when dealing with agency work. Furthermore, companies use TAW for different reasons (Stanworth and Druker, 2006), possibly resulting in a variety of strategies across (and within) organisations. What factors are associated with these differences is still an empirical issue.

This paper contributes to the discussion on union responses to TAW. Specifically, we argue that the practices unions adopt locally as a response to the HRM approach towards agency work are equally important to understanding the labour use of TAW. These responses reflect the different societal features (i.e. system of employee representation and collective bargaining) of the institutional context in which unions operate. Unions can contribute to turning precarious work into secure work. We found that the influence of local unions on the working conditions and job stability of agency workers is heterogeneous. It represents the response to the different ways management reacts to changing economic conditions inside the firm and it has legacies with the institutional context. The results are different tales explaining the outcomes for agency workers. In particular, societal differences in the national systems of employee representation and collective bargaining intersect with the firm's socio-economic conditions, while shaping the union responses to the HR management's use of TAW. This illustrates that decisions concerning the use of agency work are also influenced by negotiations between employers and employee representatives. As a result, local unions and works councils may influence the norms of treatment and the working conditions of agency workers via plant-level negotiations with HR managers.

This study demonstrates that a union's sectoral policy of inclusion towards agency work does not always reflect the practices local representatives adopt at the workplace. Social structures, different union identities, the HRM strategy and economic conditions within the firm influence plant-level bargaining over working conditions. While agency workers generally suffer from limited job security, the cases presented here show systematic differences in its extent. It can partly be reduced through the adoption of local practices aimed at favouring transitions from short- to long-term employment inside the firm. Case studies in 
Belgium illustrate that this seems more likely when the HR management adopts a long-term, strategic approach towards flexible arrangements, thereby aiming at creating formalised employment paths to stimulate commitment, performance and the overall productivity. However, it can also be argued that a firm's pressure to raise its workers' performance may explain the strategic choice of introducing employment paths. But, workplace practices are also influenced by local employee representatives' negotiation power and union identity, and the study illustrates that encompassing and union-dominated works councils were better at negotiating equality between agency and permanent workers with regard to pay and working conditions. The outcomes of these negotiated HR practices for agency workers involved a reduction in their vulnerability in terms of good working conditions and more job security. In contrast to Germany, where disorganised decentralisation in collective bargaining and 'opening clauses' made the works councils more vulnerable to management's threats of headcount reductions, the high level of coordination between sector and plant-level bargaining in Belgium contributed to reducing this challenge at the workplace level.

This research has several implications. It contributes to our understanding of the varied features and social consequences of plant-level bargaining practices of unions and management in terms of agency work. The standard literature has tended to treat union approaches towards TAW monolithically. Few studies have so far addressed the issue of 'polarised responses' when dealing with the subject. On the other hand, HR literature emphasises the ambiguity of temporary contracts in terms of the complicated relationship between user firm, work agency and agency worker. The study illustrates that the adoption of a long-term HR strategy can be beneficial in creating a sense of commitment and engagement of the temporary workforce while contributing to improving their working conditions.

The generalizability of these findings may be limited by several factors. First, the study's focus on the automotive industry with its medium-low skilled workforce, labour intensity and a high dependency on national regulation may imply that the presented results only apply to industries with similar characteristics. However, at the same time, it is striking that large differences can be observed across similar plants of the same corporation in two countries usually classified as coordinated market economies.

\section{Acknowledgment}

The research was funded by a Bijzonderonderzoekfond Onderzoekstoelage OT/10/015 and FWO ZKC2575/G.0773.11 research grants on "Multinationals in Europe between flexibility and security. A comparative company level study". We thank the editors of the special issue and the anonymous referees for their valuable comments.

\section{Notes}

1. Agency workers in Germany are covered by collective agreements for the TAW sector, no matter in which sector the user firm operates.

2. According to ACV data, more than 60 percent of the agency workforce in Belgium is unionized (ACV, 2010:13). 
3. Cf. "Presentation to the Employees Meeting", 8 January 2003

4. Cf. Company-level agreement $03 / 96$ on flexible working times (Auto1DE)

5. Cf. "Presentation to the Employees Meeting", 8 January 2003

6. Two sector-level agreements in the TAW sector in Germany from May 2010 were negotiated with two employer associations: "Interessensverband Deutscher Zeitarbeitsunternehmen (iGZ)" and "Bundesverband Zeitarbeit Personal-Dienstleistungen e.V. (BZA)". 


\section{References}

ACV (2010), Uitzendarbeid. Brussels: ACV.

Allen, J., and Henry, N. (1997), 'Ulrich Beck's 'Risk society' at work: labour and employment in the contract service industries', Transactions of the Institute of British Geographers, 22(2), 180196.

Bergström, O., and Styhre, A. (2010), 'Irish butchers rather than Irish meat: trade union responses to agency work in Sweden', Journal of Industrial Relations, 52(4), 477-490.

Bernhardt, A., and Marcotte, D. (2000), 'Is 'standard employment' still what it used to be?', in Nonstandard work: the nature and challenges of changing employment arrangements, eds. F. Carre, M. Ferber, and L. H. Golden, Champaign IL: Industrial Relations Research Association.

Bispinck, R., and Schulten, T. (2002), 'Germany: problems of a competition-oriented collective bargaining policy', in Wage policy in the Eurozone, ed. P. Pochet, Brussels: Peter Lang.

Bolton S., Houlihan M, and Laaser K. (2012) "Contingent work and its contradictions: Towards a moral economy framework", Journal of Business Ethics111: 121-132

Bundesagentur für Arbeit. (2013). Arbeitsmarkt in Zahlen: Arbeitnehmerüberlassung. http://statistik.arbeitsagentur.de/nn_31950/SiteGlobals/Forms/Rubrikensuche/Rubrikensuche_ Form.html?view=processForm\&resourceId $=210368 \&$ input_ $=\&$ pageLocale $=$ de\&topicId $=1739$ 8\&year_month $=201206 \&$ year_month.GROUP $=1 \&$ search $=$ Suchen

Connell, J., and Burgess, J. (2002), 'In search of flexibility: Implications for temporary agency workers and human resource management', Australian Bulletin of Labor, 28(4), 272-283.

Di Nicola, P. (2009), 'Precarity', International conference on precarity and flexibilisation: The new qualities of social structure, Berlin, 18-20 March 2009.

Doellgast, V. (2008), 'National industrial relations and local bargaining power in the US and German telecommunications industry', European Journal of Industrial Relations, 14(3), 265-287.

Doellgast, V.; Sarmiento-Mirwaldt, K. and Benassi, C. (2013), Alternative routes to good jobs in the service economy. A comparison of employment restructuring and HRM strategies in incumbent telecommunications firms, final project report, ESRC Grant RES-061-25-0444.

Eurofound (2006), Use of opening clauses in collective agreements, European Foundation for the Improvement of Living and Working Conditions: Dublin.

Eurofound (2008) Temporary agency work and collective bargaining in the EU, European Foundation for the Improvement of Living and Working Conditions: Dublin

European Commission (2010), Industrial relations in Europe, Brussels: European Union.

European Commission (2012), Industrial relations in Europe, Brussels: European Union.

Fudge, J. (2011), 'Global care chains, employment agencies and the conundrum of jurisdiction: decent work for domestic workers in Canada', Canadian Journal of Women and the Law, 23(1), 235264. 
Håkansson, K., and Isidorsson, T. (2012), 'Work organizational outcomes of the use of temporary agency workers', Work, Employment and Society, 33(4), 487-505.

Hall, R. (2006), 'Temporary agency work and HRM in Australia', Personnel Review, 35(2), 158-174.

Heery, E. (2004), 'The trade union response to agency labour in Britain', Industrial Relations Journal, $35(5), 434-450$.

Heery, E., and Abbott, B. (2000), 'Trade unions and the insecure workforce', in The Insecure Workforce, eds. E. Heery, and J. Salmon. London: Routledge.

Holst, H. (2013), 'Commodifying institutions: vertical disintegration and institutional change in German labour relations', Work, Employment and Society, forthcoming.

Holst, H., Nachtwey, O., and Dörre, K. (2010), 'The strategic use of temporary agency work functional change of a non-standard form of employment', International Journal of Action Research, 6(1), 108-138.

Houwing, H., Keune, M., Pochet, P., and Vandaele, K. (2011), 'Employment relations in Belgium and the Netherlands', in Research Handbook of Comparative Employment Relations, eds. M. Barry, and A. Wilkinson, Northampton, MA, USA: Edward Elgar.

Hyman, R. (2001), Understanding European trade unionism: between market, class and society. London: Sage.

International Labour Organisation (2009) Private Employment agencies, temporary agency workers and their contribution to the labour market, Paper for discussion at the workshop to promote ratification of the Private Employment Agencies Convention, 1997 (N. 181), Geneva.

Koene B. and van Riemsdijk M.(2005) "Managing temporary workers: work identity, diversity and operational HR choices”, Human Resource Management Journal, 15(1): 78-92

Lillie, N. (2011), 'Subcontracting, posted migrants and labour market segmentation in Finland', British Journal of Industrial Relations, 40(1), 148-167.

Lundy, C., Roberts, K., and Becker, D. (2006), 'Union responses to the challenges of contingent work arrangements', in The Shadow Workforce. Perspectives on contingent work in the United States, Japan, and Europe, ed. S. Gleason, Kalamazoo, Michigan: W.E. Upjohn Institute for Employment Research.

Maurice, M., Sellier, F., and Silvestre, J. (1986), The Social Foundations of Industrial Power, Cambridge MA: MIT Press.

Mitlacher, L. (2008), 'Job quality and temporary agency work: Challenges for human resource management in triangular employment relations in Germany', International Journal of Human Resource Management, 19(3), 446-460.

Perin, E. (2008), Temporary agency work and collective bargaining in Belgium, Dublin: European Foundation for the Improvement of Living and Working Conditions.

Pfeffer, J., and Cohen, Y. (1984), 'Determinants of internal labor markets in organizations', Administrative Science Quarterly, 29(4), 550-572. 
Pulignano, V. (2012), 'Recente ontwikkelingen in de Belgische sociale dialoog: beschouwingen vanuit Europees perspectief', Nieuw Arbeidsblad/Nouvelle Revue du Travail, 1(1), 108-129.

Rubery, J. (2005), 'Introduction: Fragmenting work across organisational boundaries', in Fragmenting work: blurring boudaries and disordering hierarchies, eds. M. Marchington, D. Grimshaw, J. Rubery, and H. Willmott, Oxford: Oxford University Press.

Stanworth, C., and Druker, J. (2006), 'Human resource solutions? Dimensions of employers' use of temporary agency labour in the UK', Personnel Review, 35(2), 175-190.

Ward, K., Grimshaw, D., Rubery, J., and Beynon, H. (2001), 'Dilemmas in the management of temporary agency staff', Human Resource Management Journal, 11(4), 3-21.

Wölfle, T. (2008), 'Gewerkschaftliche Strategien in der Leiharbeit' WSI Mitteilungen, 1/2008, 38-44. 
Table 1: Overview of the workplaces

\begin{tabular}{|c|c|c|c|c|}
\hline & Auto2BE & Auto2DE & Auto1BE & Auto1DE \\
\hline Country of origin & \multicolumn{2}{|c|}{ American } & \multicolumn{2}{|c|}{ American } \\
\hline $\begin{array}{l}\text { Employees } \\
\text { worldwide }\end{array}$ & \multicolumn{2}{|c|}{ About 130,000} & \multicolumn{2}{|c|}{ About 24,000} \\
\hline $\begin{array}{l}\text { Number of } \\
\text { employees ( } x \\
\text { production unit) }\end{array}$ & 2,500 & 1,700 & 1,600 & 1,500 \\
\hline Blue collar & 1,400 & 850 & 1,000 & 900 \\
\hline White collar & 1,100 & 850 & 600 & 600 \\
\hline $\begin{array}{l}\text { Main trade } \\
\text { unions } \\
\text { confederations }\end{array}$ & $\begin{array}{ll}\text { ACV-CSC, ACLVB- } & \text { ABV- } \\
\text { CGSLB, } & \text { ABVV- } \\
\text { FGTB } & \end{array}$ & IG Metall & $\begin{array}{l}\text { ACV-CSC, ACLVB- } \\
\text { CGSLB, } \\
\text { FGTB }\end{array}$ & IG Metall, CGM \\
\hline Unionization rate & $95 \%$ & $80 \%$ & $95 \%$ & $75 \%$ \\
\hline Works council & Yes & Yes & Yes & Yes \\
\hline Internal structure & $\begin{array}{l}\text { Works Council } \\
\text { (Conseil d'entreprise/ } \\
\text { Ondernemingsraad): } \\
\text { composed of } \\
\text { employee } \\
\text { representatives elected } \\
\text { at the social elections } \\
\text { on the basis of a list } \\
\text { prepared beforehand } \\
\text { by the trade unions. }\end{array}$ & $\begin{array}{l}\text { Works Council } \\
\text { (Betriebsrat): } \\
\text { composed of } \\
\text { employees who, } \\
\text { regardless of whether } \\
\text { or not they are trade } \\
\text { union members, have } \\
\text { the right to stand as } \\
\text { candidates. }\end{array}$ & See Auto2BE & See Auto2DE \\
\hline $\begin{array}{l}\text { Locally } \\
\text { negotiated share } \\
\text { of agency workers }\end{array}$ & $\begin{array}{ll}\text { No agency } & \text { work, but } \\
20 \% & \text { fixed-term } \\
\text { workers } & \end{array}$ & Quota 20\% & Quota $5 \%$ & $\begin{array}{lr}\text { Quota-15\% } & (40 \% \\
\text { during } & \text { holiday } \\
\text { seasons }) & \end{array}$ \\
\hline
\end{tabular}

